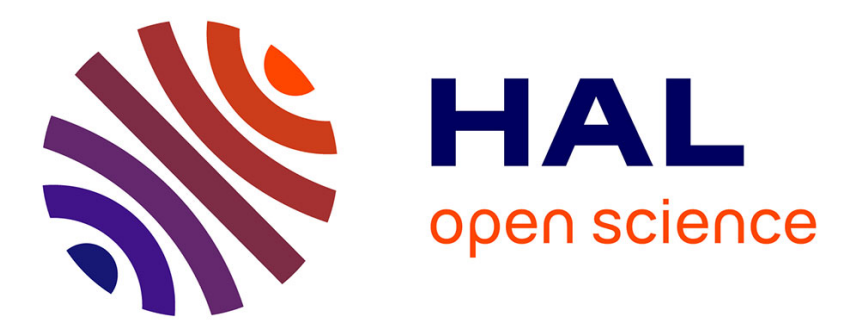

\title{
Critical citizenship at work: the intriguing combination of democratic and epistocratic criticism of representation in French public opinion \\ David Copello
}

\section{- To cite this version:}

David Copello. Critical citizenship at work: the intriguing combination of democratic and epistocratic criticism of representation in French public opinion. French Politics, 2019, 17 (4), pp.433-450. 10.1057/s41253-019-00096-4 . hal-02507497

\section{HAL Id: hal-02507497 \\ https://hal.science/hal-02507497}

Submitted on 13 Mar 2020

HAL is a multi-disciplinary open access archive for the deposit and dissemination of scientific research documents, whether they are published or not. The documents may come from teaching and research institutions in France or abroad, or from public or private research centers.
L'archive ouverte pluridisciplinaire HAL, est destinée au dépôt et à la diffusion de documents scientifiques de niveau recherche, publiés ou non, émanant des établissements d'enseignement et de recherche français ou étrangers, des laboratoires publics ou privés. 


\title{
Critical citizenship at work: the intriguing combination of democratic and epistocratic criticism of representation in French public opinion
}

Published in French Politics, Vol. 17, n¹4, 2019, pp. 433 - 450

DOI: $10.1057 / s 41253-019-00096-4$

David Copello, david.copello@ casadevelazquez.org

Calle de Paul Guinard, 3 - 28040 Madrid

$+33629630453$

\begin{abstract}
The crisis of representative democracy has been at the core of extensive research in contemporary political science. However, empirical works have mostly highlighted sceptical attitudes, and few studies have focused on critical citizens' aspirations. This article explores the combined support for random selection and skills-testing of decision makers in French public opinion. Drawing on data from the CEVIPOF 2017 French electoral survey, it discusses: 1) the level of concern and support for such institutional changes; 2) the intriguing convergence of both top-down and bottom-up criticism of the representative system; 3) the impact of education and 4) the impact of political preferences on attitudes toward random selection and skills-testing of representatives. We find that education has a negative effect on both variables, and that classical political variables (Left-Right scale) have a non-linear impact. The stronger impact on variables is provided by critical citizenship types, defined by satisfaction/dissatisfaction with current democracy and aspirations for change.
\end{abstract}

Keywords: critical citizenship; random selection; representative democracy; epistocracy; radical democracy; political competence. 


\title{
Critical citizenship at work: the intriguing combination of democratic and epistocratic criticism of representation in French public opinion
}

\author{
David Copello, david.copello@ casadevelazquez.org \\ Calle de Paul Guinard, 3 - 28040 Madrid \\ $+33629630453$
}

\section{Introduction}

The balance between democracy and 'aristocracy' is at the core of the contemporary model of representative government ${ }^{\mathrm{i}}$. Ordinary citizens elect a minority of individuals who govern and legislate in their name. An elite selected by election is in charge, as long as ordinary citizens consent to it (Manin, 1995). However, this equilibrium is not without tensions, which nourish much contemporary work in political science. Some of this work discusses the broad range of criticism aimed at representative systems. For the sake of analysis, such criticism can be divided into two categories: bottom-up and top-down. These two types of criticism, their interconnections and the conceptual tools used to measure them will be the focus of this article. On the one hand, the idea of a democratic deficit, and of disaffection toward western political systems, is frequently highlighted in public debate and in academic research (Norris, 2011). Such debate facilitates reflection on how ordinary citizens might become re-enchanted with politics. It reveals the need to enhance citizens' involvement in political institutions beyond elections. The logic of decentralisation, and the creation of new participatory and deliberative democratic forms paralleling representative institutions, have become a primary public concern and have led to a number of innovative experiments (Blondiaux, 2008; Manin and Blondiaux, 2002). Among these measures, whose aim is to promote the democratisation of democracy, the use of random selection has been gaining momentum in the French public sphere in recent times. This followed a series of essays and academic research papers concerned with the political implications of sortition (Delannoi, 2011, 2019; Delannoi and Dowlen, 2010; López- 
Rabatel and Sintomer, 2019; Rancière, 1995; Sintomer, 2011). During the 2017 French presidential campaign, random selection was also referenced in the political programme and discourse of several candidates. Emmanuel Macron contemplated the possibility of drawing citizens every year to audit his presidency. Jean-Luc Mélenchon advocated a constitutional assembly partly composed of randomly selected citizens. The socialist candidate, Benoît Hamon, proposed appointing a certain proportion of senators by drawing lots among ordinary citizens. During the 2018/2019 yellow vests movements, grassroots popular mobilisations have also raised the issue of random selection, at the core of political discussions surrounding the grand débat national organised a few months later by the French government ${ }^{\mathrm{ii}}$. Random selection is thus connected to the expression of bottom-up criticism addressed at representative democracy. It is a means to give more power to ordinary citizens in order to compensate for the 'aristocratic' tendencies of the current regime.

On the other hand, a strengthening of experts' role in political institutions has also been observed in recent decades, contradicting the call for random selection (Cusso and Gobin, 2008; Dumoulin et al., 2005; Leighninger, 2006; Restier-Melleray, 1990). It can be perceived as the corollary to top-down criticism of representative democracy. This new credit given to experts has been the object of in-depth discussion: it is sometimes denounced as a post-democratic (Crouch, 2004), technocratic (Habermas, 1968) or expertocratic (Estlund, 2008) downward slide. According to the political ideology described (and criticised) in these essays, power should be exerted by a minority isolated from the people. This minority is supposedly more competent to make decisions: the rule of the majority and the rule of knowledge are conceived as incompatible in some respects. The status enjoyed by the president of the European Central Bank (ECB) provides a good example of this anti-democratic tendency. The ECB president is a permanent civil servant, whereas former presidents of national central banks were usually revocable by the head of state, and thus indirectly subject to the logic of representation. The 
independent judgement of ECB administrators is hence protected (theoretically) from popular passions and electoral fluctuations (Jabko, 2001), which are subject to the law of numbers supposedly opposed to the law of reasoning (Elster, 1984, 2000). Here, the legitimacy of power relies on the expertise and skills of the individual exercising it, and not according to his or her electoral popularity. Jason Brennan provides a systematic defence of this ideological trend in his essay Against Democracy. In this book, he argues for a new type of government: epistocracy, a system that "distributes political power in proportion to knowledge or competence" (Brennan, 2016, p. 208). To extend these discussions, one could consequently imagine an institutional system in which the exercise of political functions would require a series of skills measured through testing. The idea of a skills test, taken by elected representatives before they are allowed to take office, can thus be seen as an epistocratic tool to correct the dysfunctions of representative democracy. It expresses top-down criticism of current political regimes, hence favouring the selection of 'competent' citizens in the race for power, in order to compensate for the alleged populist and/or irrational tendencies of ordinary citizens when it comes to making electoral choices.

Several counter-models of citizenship are thus present in the public sphere as well as in theoretical arenas. These criticisms of different sorts directed at representative democracy question the ability of citizens to participate in government: they could be enhanced by innovative measures for the selection of political leaders and for decision-making. Some suggest that political abilities are evenly spread among the people (which would favour a recycling of Ancient Athenian uses of random selection for instance). Others believe such abilities are limited to a privileged few, in which case they should be measured, evaluated and recognised officially (e. g. through the invention of a skills test for elected representatives). Research in the sociology of public opinion has frequently addressed these issues from a purely negative perspective. Positive aspirations embedded in such criticism have often been 
overlooked, despite the fact that they convey a profound desire for the representative system to change. Approaches highlighting negative perceptions of the existing political system tend to predominate, rather than the alternative scenarios contemplated by critical citizens. Critical citizenship is thus frequently seen as merely the expression of a wish to exit democracy, and the desire of authoritarian leadership. This attitude is usually conceived as the corollary of a “cumulative downward spiral" (Nye et al., 1997) of "scepticism, lack of civism and withdrawal" (Mayer, 2002, p. 87), ending in representative democracy's self-destruction. There therefore seems to be a divorce in contemporary political science, between enthusiastic political theory on the one hand, and pessimistic political sociology on the other. While political thought provides a theoretical understanding of citizens' positive aspirations, political sociology tends to privilege critical citizenship's negative dimension, boiled down to a rejection of the existing political system. $^{\text {iii }}$

This article aims to reverse such a trend. It analyses the attitude of French citizens toward two types of measures that are critical to representative government: random selection of political leaders and skills-testing for elected officials. These two variables serve as proxies reflecting support for bottom-up democratic reforms of representation (random selection) and for topdown epistocratic reforms of representation (skills-testing). After explaining the methodology used in this research, the article discusses a series of issues related to the topic of critical citizenship: 1) Does the public share concerns and/or aspirations that are usually formulated by political theorists?; 2) Does the public perceive top-down and bottom-up criticism as contradictory, as would generally be the case in the political theory literature?; 3) Random selection and skills-testing raise the issue of competence/incompetence in the political sphere: what then is the impact of education on support for both measures?; 4) How can approval of random selection and skills-testing be related to respondents' political preferences? 


\section{Methodology}

The objective of this article is to deepen our understanding of the diverse shapes taken by critical citizenship in France. Critical citizens must not be perceived only as cynical actors, distrustful individuals and/or abstainers, who see politics from an exclusively negative perspective. They are also actors endowed with aspirations that could fuel political change. Based on such premise, the article emphasises the interaction between a priori divergent attitudes toward change among critical citizens.

Subsequent analyses are based on responses to a questionnaire on "Democracy and Citizenship" undertaken from December 2-7, 2016 among a population of 18, 013 individuals aged 18 years and over, registered as voters and constituting a representative sample of the French population. The questionnaire was part of the 2017 French Electoral Survey (wave 9) carried out by the Centre de Recherches Politiques de Sciences Po (CEVIPOF). It consisted of eight questions. The analysis produced in this article mainly focuses on one of these questions: "People have different opinions about how France might be better governed. Do the following propositions seem pertinent to you?" Survey respondents were then asked to grade six different items from 0 to 10 (with higher values corresponding to stronger approval), among which: a) "We should test and evaluate the skills of elected representatives before they take office" $(67 \%$ iv replies from 7 to 10, mean level: 7.37); b) "At least some decision-makers should be randomly selected from among ordinary citizens" (42\% replies from 7 to 10 , mean level: 5.74$){ }^{\mathrm{v}}$

Compared to other existing surveys of public opinion (European Values Study, World Values Survey, Comparative Study of Electoral Systems, Baromètre de la Confiance Politique), this module of the 2017 French Electoral Survey presented an entirely novel feature. Indeed, it offered a greater number of alternative political options on which respondents could give their opinion. Support and rejection of current political forms are usually measured with scales discussing "satisfaction with the way democracy works" (Comparative Study of Electoral 
Systems 2011-2016) or "confidence in institutions" (Baromètre de la Confiance Politique 2017). In the above studies, critical citizenship is appraised from a purely negative perspective. Items on alternative political models have however been added to some surveys, especially with regards to "government by experts". Surveys such as the European Values Study, World Values Study and Baromètre de la Confiance Politique ask respondents to give their opinion on "having experts, not government, make decisions according to what they think is best for the country" (European Values Study 2008, World Values Survey 2010 - 2012, Baromètre de la Confiance Politique 2017). Yet the selection of these experts remains unformulated in these questionnaires $^{\mathrm{vi}}$. Its interconnection with the electoral system remains at an implicit level, while the interpretation of results generally associates support for decision-making by experts with a desire to exit democracy. On the contrary, our "skills-testing" variable can be understood here as a device allowing for government by experts that explicitly affects how current electoral systems function (without annihilating them). Moreover, when the "Democracy and Citizenship" module of the 2017 French electoral survey was undertaken (in December 2016), citizen support for random selection of political decision makers had never before been estimated. $^{\text {vii }}$ The specificity of our trace-back protocol thus resides in the fact that it measures simultaneously, within a single survey module, both levels of support for random selection (y1) and for skills-testing of elected representatives (y2). The theory underlying the formulation of this survey considered $\mathrm{y} 1$ and $\mathrm{y} 2$ as opposing aspirations, but we did not assume that respondents themselves would interpret $\mathrm{y} 1$ and $\mathrm{y} 2$ as mutually exclusive. They were thus invited to grade each variable separately, so as to evaluate what we might call their level of coherence: in this case, this would consist in a negative relation between the two variables. In this article, we display both descriptive statistics (in percentages of approval/disapproval/neither approval nor disapproval) and a regression model, for which the 
two variables are recoded to the $0-1$ range, with higher values corresponding to stronger support.

Apart from our two key variables, we use a set of socio-demographic and political variables. Among socio-demographic variables, the income scale is a categorical variable that indicates respondents' net monthly household income. It is divided as follows: less than 1250 euros, 1250 to 1999 euros, 2000 to 2499 euros, 2500 to 3499 euros, 3500 to 5999 euros, 6000 euros and more. Gender is a dummy variable taking the value 1 for female respondents. Age is a continuous variable coded in years. Religiosity is based on temple attendance: it is a five-point scale that ranges between 0 "never" and 1 "at least once a week". Education is a four-point scale that indicates respondents" highest diploma: it ranges from 0 "no qualification or certificate of primary education only" to 1 "University degree".

Three types of political variables are used in the analysis. The Left-Right scale is based on selfplacement and coded in five categories that range between 1 "far-left" and 5 "far-right". The scale of interest for politics is coded on an 11-point scale, ranging from "not at all" to "a lot", and recoded into the $0-1$ range for the purpose of analysis. Finally, we added a critical citizen type variable, based on a question regarding "opinions on democracy" - it is coded in four categories, detailed later for issues of clarity.

\section{Reforming representation: a popular concern}

The question arises as to whether or not the main distinctions established by political theorywhich usually delineate distinct normative choices and even traditions of thought - make sense to survey respondents. According to the survey results analysed here, a form of resonance exists between critical political theory and citizens' aspirations. Indeed, we observe a high percentage of clear-cut opinions on skills-testing and random selection. 
In their replies to each of these two proposals, about two thirds of respondents formulate strong opinions, by placing themselves either between 0 and 3 or between 7 and 10 on the 11-point scale. Indeed, by cumulating 0 to 3 and 7 to 10 responses, we observe over $60 \%$ of clear-cut opinions in both cases. Fully $72 \%$ of respondents give a clear-cut reply to the question on skillstesting, and $62 \%$ do likewise on the issue of random selection. Interestingly, these results are relatively close to those observed for other more classical items tested in the same section of the questionnaire (e.g. greater use of referenda: $70 \%$ clear-cut opinions; or mandatory voting: $66 \%$ clear-cut opinions). Admittedly, there are variations in that area, but they are limited. ${ }^{\text {viii }}$ It is thus worth observing that respondents do not seem particularly disorientated by the nature of the issues raised in the questionnaire: a large majority feels able to give a straight answer on random selection and skills-testing.

The intermediate option ( 4 to 6 on the proposed 11-point scale) is thus chosen by a minority of respondents. This might seem surprising given the nature of the issues raised in the questionnaire. Taking into account the fact that random selection remains an unfamiliar democratic tool, it would have been reasonable to expect a high percentage of intermediate responses - also considering that the "I don't know" option was not proposed to interviewees. Nevertheless, although substantial (38\%), these responses remain a minority here. We can consider clear-cut opinions as a proxy indicator of how well respondents understand the questions, and as a reflection of how pertinent they believe the issues to be. In this case, skillstesting and random selection appear as measures that make sense for most of those interviewed during this survey.

Further, the clear-cut opinions observed in the sample show a very strong level of support for both proposed measures. Random selection garners two thirds of positive replies among clearcut responses ( $42 \%$ agree [7 to 10], $21 \%$ disagree [0 to 3]). Although random selection is the less favoured proposal in the questionnaire, it nevertheless obtains a respectable total. As for 
skills-testing, it secures a landslide majority - almost nine positive opinions out of ten clear-cut responses (67\% agree; $5 \%$ disagree). In both cases, when citizens feel able to provide a clearcut answer to the questions, a majority of their replies are positive. Before going further, it should be remembered that this is no exception: the four other proposals for a renewed democracy (increasing the use of referenda so that citizens have a final word on political decisions; consulting groups of ordinary citizens more frequently; increasing the resemblance between leaders and the diversity of contemporary society; mandatory voting in all elections) were approved along the same lines.

\section{The intriguing convergence of bi-directional criticism}

One of the issues raised in this study concerns the ability of citizens to formulate coherent opinions about different criticisms of democracy. Arguing for a democratisation or radicalisation of democracy ${ }^{\mathrm{ix}}$ (random selection) or for a reinforcement of representative 'aristocracy' (skills-testing) can be considered very different options from a theoretical perspective. In that regard, a reasonable expectation as regards survey results was that approval of random selection and skills-testing would tend to be mutually exclusive. In that perspective indeed, a coherent line of criticism would adopt a zero-sum logic in combining the two variables. However, the results obtained through the survey disprove this prediction.

In fact, attitudes toward random selection and skills-testing tend to converge: they seem to go hand in hand in the minds of critical citizens, and not to be perceived as contradictory. Descriptive statistics displayed in Table 1 show that a majority (51\%) of those in favour of skills-testing also support random selection. The same phenomenon occurs with those in favour of random selection, depicted in Table 2: a huge majority of them (83\%) is favourable to skillstesting. Conversely, among those who disapprove of skills-testing, $64 \%$ also reject random 
selection. In these three cases, responses are not mutually exclusive at all. There is no conflictual trend between the two types of criticism: on the contrary, they converge.

\section{TABLE 1}

\section{TABLE 2}

There remains one exception within this generalised convergence phenomenon: among respondents unfavourable to random selection (21\% of the total sample), one half $(50 \%)$ supports the creation of skills-testing for elected officials. Nevertheless, these "coherent" critical citizens only embody a tiny minority of those surveyed, around $10 \%$ of the total sample. Moreover, their propensity to approve of skills-testing remains lower than the average in the total sample (50\% versus $66 \%$ ). Somehow surprisingly, there is thus a positive and substantial association between attitudes toward random selection and skills-testing. The tendency to support the latter always positively correlates with approval of the former (correlation coefficient of 0.36): the more favourable the attitude is to skills-testing, the more favourable it is to random selection (and vice-versa).

Critical citizenship (as measured by attitudes toward random selection and skills-testing) could thus be considered as incoherent, if we consider that giving more power to competent citizens (top-down criticism), and giving more power to ordinary citizens (bottom-up criticism) are incompatible aspirations. On the contrary, most respondents perceive both measures as complementary rather than mutually exclusive. Of course, actual combinations of both devices are possible. This was the case in Ancient Athens, where sorted individuals had to undergo a personal scrutiny (the dokimasia) before being allowed to legislate in the city council (Boulè) for instance. This twofold process enabled ordinary citizens to participate in government while 
preventing undesirable ones (e.g. disrespectful to family, tax evaders, deserters or oligarchical sympathisers) from interfering with the polity (Adeleye, 1983). However, crediting a massive number of respondents from supporting such a specific combination of institutional mechanisms would seem implausible. A more reasonable explanation would link the observed correlation of random selection and skills-testing approval to an overall wish to control governing elites, and to limit the power of representatives elected by universal suffrage. Such a perspective raises the issue of political discontent variables and social variables associated with this criticism of representation. Where in the population do we find such a trend combining support for democratisation and epistocratisation at the same time?

\section{Impact of education}

We turn to thick sociological variables to evaluate variations in support for random selection and skills-testing. From a theoretical perspective, both measures whose approval is analysed in this article are strongly connected to the issues of (political) competence and education. The skills-testing of elected representatives consists in measuring an expertise that, in the context of the survey, comes down to political competence. On the other hand, accepting the idea of random selection implies thinking either: a) that political competence is evenly spread among the population so that anybody would be able to legislate and/or govern; b) that competence does not matter in politics; c) that the democratic advantages of random selection compensate for its tendency to favour "the first comer" (Rancière, 2005).

Classical political sociology literature establishes a strong connection between political competence and social status, notably determined by levels of income and education (Bourdieu, 1977; Gaxie, 1978). The effect of educational qualifications especially lies at the core of discussion in research on political competence (Highton, 2009; Luskin, 1990; Tiberj, 2004): "among social class indicators, the level of education always has the highest correlation with 
variables of political knowledge" (Gaxie, 1978, p. 159). Competence and the feeling of competence in politics are thus traditionally considered as prevalent among individuals who are well-educated degree holders. Education hence appears as a crucial variable to analyse the results of this survey.

A reasonable anticipation of the results collected through the questionnaire on random selection and skills-testing would have been to obtain a binary structure of responses strongly cleaved along educational lines. Respondents with a higher level of education would have been expected to reward competence, favouring skills-testing and opposing random selection. On the other hand, lesser-educated citizens would be expected to promote the ordinary citizen's perspective in the selection of political leaders, and in rejecting competence as a requirement to take office. They would thus have been expected to favour random selection and to oppose skills-testing. Following that line of thought, education should limit the convergent tendency observed in general results.

In Tables 3 and 4, we consider four different categories of education levels: 1) no qualification \& certificate of primary education alone (CEP); 2) junior school certificate (BEPC) \& vocational qualifications (CAP \& BEP); 3) high school diploma (BAC); 4) university degree. Descriptive statistics contradict the above hypotheses and show that rejection of both proposals progresses systematically when the level of education rises above BEPC, CAP and BEP. Better educated respondents are less likely to support random selection and skills-testing. Three significative categories must be highlighted here: non-baccalauréat holders, baccalauréat holders and university graduates. The results for baccalauréat holders are close to the general average of support for both measures: $43 \%$ for random selection $(+1 \%)$ and $68 \%$ for skillstesting (+1\%). Respondents holding a qualification lower than the baccalauréat are distinctly above the overall approval average, between $3 \%$ and $7 \%$ higher in both cases. On the contrary, university graduates place themselves clearly under the overall approval average, with a gap of 
4\% for both proposals: $38 \%$ support random selection (vs $42 \%$ ) and 63\% (vs 67\%) are in favour of skills-testing. This last proposal creates the highest level of circumspection (or lack of understanding) among individuals with the highest level of education in the sample: $31 \%$ of them neither agree nor disagree with skills-testing (vs $28 \%$ in the total sample). Further, a more in-depth analysis of university graduates shows that the longer and/or the more prestigious the university career is, the more unfavourable respondents become to both proposed measures. Indeed, random selection approval scores as follows: $43 \%$ among BAC holders, $40 \%$ among $\mathrm{BAC}+2$ or $\mathrm{BAC}+3,33 \%$ among $\mathrm{BAC}+4$, and $32 \%$ among (former) students of the French Grandes Écoles (HEC, Sciences Po, École Normale Supérieure, etc.). The same is true for skills-testing, which receives clear-cut approval from 68\% BAC holders, $66 \%$ among those holding a BAC+2 and BAC+3 qualification, 59\% BAC+4 holders and 57\% Grandes Écoles graduates.

In order to analyse educational correlates of support for random selection and skills-testing in more detail, we estimate a bivariate regression model (see Appendix). This includes income, age, gender, religiosity as well as further political variables - that will be explored in the next section. Overall, the education contrast highlighted above remains statistically significant. It is stable for random selection, although the effect of education is somewhat smaller as concerns skills-testing. The effect of age, positively correlated with support for the latter, partly explains this. Among socio-demographic variables, age has indeed the strongest effect on both measures, and follows the mutually exclusive logic we expected to find in results. Education is thus not the only relevant variable to account for social contrasts on random selection and skills-testing. However, given its connection with the issues of knowledge and competence that are key to discussing both proposed measures, its effect remains particularly interesting. This is especially true with regard to the issue of coherence. Indeed, education does not compensate for the generalised tendency to simultaneously approve (or disapprove) random selection and skills- 
testing. On the contrary, it stresses it: education increases the probability of rejecting the two proposed reforms, in line with previous research pointing the most educated citizens' preference for representative democracy, compared to direct democracy and stealth democracy (Coffé and Michels, 2014).

\section{TABLE 3}

\section{TABLE 4}

\section{Impact of political preferences}

We shall now look at how opinions on random selection and skills-testing vary according to political preferences. We included three political variables in our regression model (see Appendix): self-placement on a Left-Right scale (ordinal variable coded 1 to 5), scale of interest for politics (interval variable coded 0 to 1 ) and a categorical variable measuring critical citizenship types, built as follows:

Different opinions can be expressed on the way in which democracy functions in France. Among the following opinions, choose the one that is closest to yours:

1) Our democracy works well, there is no reason to make real change (score of 9\%; respondents labelled as "non-critical citizens").

2) Several aspects of our democracy should be improved (score of $48 \%$, respondents labelled as "demo-reformers").

3) Establishing true democracy in France would call for radical change (score of $35 \%$, respondents labelled as "demo-transformers").

4) Democracy does not work, we need to find a new political system (score of $8 \%$, respondents labelled as "demo-exiters") ${ }^{\mathrm{x}}$.

While interest for politics has a marginal and (in one out of two cases) non-significant effect in the model, the Left-Right scale indicates important differences between respondents (in spite of several non-significant categories in the case of skills-testing). Indeed, the propensity to 
support random selection is higher on the far-left, while the highest probability of supporting skills-testing is on the far-right. However, none of the explained variables has a linear relation with the Left-Right scale: actually, support for both measures rises significantly among far-left, far-right but also among Centre respondents. Rather than a Left-Right division of preferences, the regression model provides evidence that the dependent variables score higher among those who feel more distant toward traditional bipolar politics, organised around centre-right/centreleft parties.

In order to complement these results, we now turn to the previously exposed critical citizen typology, to evaluate its impact on random selection and skills-testing approval. Descriptive statistics displayed in Tables 5 and 6 show important differences between critical citizen profiles. For instance, it can be noticed that non-critical citizens are the least favourable to random selection (25\% agree vs 38\% disagree) and skills-testing (52\% agree vs $9 \%$ disagree). On the other hand, demo-transformers are the most favourable to random selection (52\% agree vs only $14 \%$ disagree) and skills-testing (74\% agree vs $4 \%$ disagree). The intermediate option for random selection (4 to 6 on the 11-point scale) prevails among demo-reformers (41\%), while the intermediate option on skills-testing scores the highest among non-critical citizens.

The distribution of responses according to citizen profiles shows important differences in preferences expressed. Positive responses increase if we consider non-critical citizens $(25 \%$ favourable opinions on random selection and $52 \%$ on skills-testing), then demo-reformers (respectively $36 \%$ and 64\%) and demo-transformers (52\% and 74\%). As can be observed however, there is no substantial difference between the latter and demo-exiters (51\% and 73\%). Hence, if we focus on deviation from the average alone, a more significant clean cut between two clusters stands out: non-critical and demo-reforming citizens (approval rates under the average) and demo-transforming and demo-exiting citizens (approval rates above the average). The structure of opinions thus appears as binary rather than quaternary. These results are 
confirmed by the regression model. If one takes "non-critical citizens" as a reference: 1) critical citizen types have a significant effect on the two dependent variables, and are the most defining independent variable in the model — its effect ranges from 0.06 to $0.19 ; 2$ ) regression does not show any substantial difference between demo-transformers (random selection: 0.19; skills test: 0.11) and demo-exiters (random selection: 0.18; skills-test: 0.12 ) regarding the two dependent variables.

Looking at the results obtained in this part of the questionnaire, the distinction between demotransforming citizens and demo-exiting citizens becomes slightly blurred. There is no straightforward division between demo-transformers aspiring to a bottom-up radicalisation of the democratic regime on the one hand and demo-exiters aspiring to a top-down dedemocratisation through the skills-testing of representatives. On the contrary, the answers given by both demo-transformers and demo-exiters are very similar, as their differences generally do not exceed $1 \%$ in descriptive statistics. As might be expected, demo-transformers are particularly in favour of random selection $(+10 \%$ compared to the average in the overall sample), but they also strongly support skills-testing (+7\%). The same goes for demo-exiters: they particularly approve of both skills-testing (+6\%) and random selection $(+9 \%)$.

It is thus clear from these results that approval for random selection and skills-testing of elected representatives are strongly and positively associated with levels of discontent and aspiration for alternative political systems. However, as regards support for both measures, there is no substantial difference between partisans of radicalised democracy (bottom-up criticism) and partisans of epistocratic institutions (top-down criticism), and no linear distribution of Leftwing and Right-wing respondents.

\section{TABLE 5}




\section{TABLE 6}

\section{Conclusion}

In the last decades, much of the political sociology literature on citizenship and public opinion has been concerned with democratic discontent. In France, extant work has focused on degrees of satisfaction/dissatisfaction with representative democracy. This attitude is generally measured through scales estimating rejection of the current political system. In parallel, political theory has actively discussed alternative political mechanisms questioning the principles of liberal democracy. Radical democracy or epistocracy (among others) have been core issues in these debates, but popular support or rejection for such theoretical innovations is seldom explored. This research provides insights into how French citizens perceive a series of political mechanisms that would significantly transform representative democracy. It does so by building and testing novel indicators inspired by developments in contemporary political theory. What is the people's reaction to such a democratic idea as the random selection of decision makers? How do people react to the epistocratic perspective of creating a skills test for elected representatives before they are allowed to take office? And is there a connection or an opposition between both aspirations?

This exploratory research reaches four main conclusions. First, general results of the survey show a substantial concern for random selection and skills-testing. Both items, despite their novelty, arouse a large majority of clear-cut responses, widely inclined toward approval. Second, support for random selection and approval of skills-testing are positively correlated: in interviewees' responses, both measures tend to be combined rather than opposed. Third, education has a negative effect on both variables. Having more diplomas does not predict higher support for epistocracy at all. Neither does it entail favouring a radicalisation of democracy through random selection. Lastly, political preferences associated with our two dependent 
variables do not straightforwardly follow classical variables such as the Left-Right scale. A better prediction of support for random selection and skills-testing is given by attitudes toward democracy and critical assessments of what should be done to improve political institutions' performance. In this perspective however, we do not identify substantial differences between those who would favour "radical change" to reach a "true democracy" and those who think "democracy does not work" and should be relinquished.

Future research could build on and extend these conclusions in several ways. First, the positive correlation of support for random selection and skills-testing calls for further reflections in the area of political theory. While issues of epistocracy and radical democracy seem to be rather disconnected from a theoretical point of view, it might prove fruitful to undertake discussions on potential cross-fertilisations. A possible research direction would consider the epistemic boundaries of political participation imagined (explicitly or implicitly) in radical democratic theory, so as to assess the details and acceptable extension of a popular-supported introduction of random selection in renewed democracies. Another research direction would consist in studying non-democratic applications of sortition in epistocratic designs, thus contributing to ongoing debates on the democratic "nature" of random selection (Bonin, 2017; Cervera-Marzal and Dubigeon, 2013; Delannoi et al., 2013; Talpin, 2019).

Further, the measure of epistocracy (in general) and skills-testing (in particular) should be sharpened to expand on the existing data, and build more detailed analyses of citizens' appraisal on the issues related to political competence. In this article, "skills" have been presented as a general value. Their materialisation into explicit areas of expertise (e.g. scientific, technical, etc.) or knowledge, as well as their proximity with other assets such as "experience" or even "common sense" should be tested in further questionnaires. These new measures may prove relevant for a more detailed understanding of critical citizens' relations to epistocracy, and shall 
provide interesting insights into what French citizens perceive as the main necessary "skills" in politics.

\begin{abstract}
${ }^{i}$ The author wishes to thank the other members of the "Democracy and the Citizen" research group at the CEVIPOF (Bruno Cautrès, Janie Pélabay, Bernard Reber and Réjane Sénac), who fuelled stimulating discussions on this article's topic in the past years. Methodological and technical advice provided by Bruno Cautrès and Flora Chanvril-Ligneel was greatly appreciated, as were the suggestions of Thomas Vitiello and Chantal Barry. Special thanks should also be given to Pavlos Vasilopoulos for his decisive recommendations on the analysis of data.
\end{abstract}

${ }^{\text {ii }}$ Especially after the Convention Citoyenne pour le Climat, composed of 150 randomly selected members, was created in 2019.

iii These general conclusions must not hide the diversity of approaches to the issue of critical citizenship within political sociology. Some work has shown that it also includes positive aspects and attitudes (see for instance: Dalton, 2007; Muxel, 2002, 2018).

iv In this article, all percentages have been rounded up to the nearest whole number.

" The four other proposals scored as follows: 1) "Groups of ordinary citizens should be consulted more frequently", $72 \%$ replies from 7 to 10 (mean: 7.56 ); 2) "Leader profiles should reflect the diversity of today’s society", 63\% replies from 7 to 10 (mean: 7.09); 3) "There should be greater recourse to referenda to ensure that citizens have the final say", $61 \%$ replies from 7 to 10 (mean: 7.05 ); 4) "Voting should be mandatory for all elections", 51\% replies from 7 to 10 (mean: 6.42).

${ }^{\text {vi }}$ The opposition between government by experts and the electoral system appears more explicitly in another item of the CEVIPOF's Baromètre de la Confiance Politique 2017. Here, respondents were invited to give their opinion on the following proposal: "Our government would work better if decisions were made by unelected and independent experts rather than by politicians or citizens". However, from a theoretical point of view, this formulation combines an epistocratic conception of government (through the reference to "unelected experts") with a deliberative conception of decision-making (promotion of "independent" judgement as opposed to partisan ways of settling disputes). Its interpretation within the framework of this article would thus be problematic.

${ }^{\text {vii }}$ Since then, such a measurement has been included in the CEVIPOF's Baromètre de la Confiance Politique 2017, 2018 and 2019. Overall agreement (fluctuating between 42 and 48\%) was measured by the following statement: "Democracy would work better in France if members of parliament were in fact randomly selected citizens". 
viii Clear-cut replies oscillate between $62 \%$ for random selection and $76 \%$ for the following item: "France would be governed better if we consulted groups of ordinary citizens more frequently".

ix Interpretations of notions such as the "radicalisation of democracy" or "radical democracy" vary substantially between the different reference authors. However, in the literature of political theory, they all refer to a reinforcement of popular power (of ordinary citizens) within democratic systems. Therein lies a "radicalisation" of democracy in the sense that the people are considered the root, the founding pillar of democracy. Radical democracy therefore appears to be a return to the sources of the democratic regime (Cohen and Fung, 2004).

${ }^{x}$ On the choice of these labels, and for an in-depth analysis of this question, see the other contribution to this special issue (Pélabay and Sénac, 2019). 


\section{References}

Adeleye, G. (1983) The purpose of dokimasia. Greek, Roman, and Byzantine Studies 24(4): $295-306$.

Blondiaux, L. (2008) Le nouvel esprit de la démocratie: actualité de la démocratie participative. Paris: Seuil.

Bonin, H. (2017) Sur la «nature» du tirage au sort en politique: dialogue entre hasard et élection. Politique et Sociétés 36(1): 3-23.

Bourdieu, P. (1977) Questions de politique. Actes de la recherche en sciences sociales 16(1): $55-89$.

Brennan, J. (2016) Against Democracy. Princeton: Princeton University Press.

Cervera-Marzal, M., and Dubigeon, Y. (2013) Démocratie radicale et tirage au sort. Raisons politiques (50): 157-176.

Coffé, H., and Michels, A. (2014) Education and support for representative, direct and stealth democracy. Electoral Studies 35: 1-11.

Cohen, J., and Fung, A. (2004) Radical Democracy. Swiss Journal of Political Science 10(4): 23-34.

Crouch, C. (2004) Post-democracy. Malden: Polity.

Cusso, R., and Gobin, C. (2008) Du discours politique au discours savant: le changement politique mis hors débat? Mots. Les langages du politique (88): 5-11.

Dalton, R. (2007) The Good Citizen: How a Younger Generation is Reshaping American Politics. Washington D.C.: CQ Press.

Delannoi, G. (2011) Le tirage au sort : une approche démocratique. Esprit (8): 153-161.

Delannoi, G. (2019) Le tirage au sort: comment l'utiliser. Paris: Presses de Sciences Po.

Delannoi, G., and Dowlen, O. (Eds.) (2010) Sortition: Theory and Practice. Exeter: Imprint Academic. 
Delannoi, G., Dowlen, O., and Stone, P. (2013) The lottery as a democratic institution. Dublin: Policy Institute, Trinity College Dublin.

Dumoulin, L., La Branche, S., Robert, C., and Warin, P. (2005) Le recours aux experts : raisons et usages politiques. Grenoble: Presses Universitaires de Grenoble.

Elster, J. (1984) Ulysses and the sirens: Studies in rationality and irrationality. Cambridge, Mass.: Cambridge University Press.

Elster, J. (2000) Ulysses unbound: Studies in rationality, precommitment, and constraints. Cambridge, Mass.: Cambridge University Press.

Estlund, D. M. (2008) Democratic Authority: A Philosophical Framework. Princeton: Princeton University Press.

Gaxie, D. (1978) Le cens caché : inégalités culturelles et ségrégation politique. Paris: Seuil. Habermas, J. (1968) Technik und Wissenschaft als Ideologie. Frankfurt: Suhrkamp.

Highton, B. (2009) Revisiting the Relationship between Educational Attainment and Political Sophistication. The Journal of Politics 71(4): 1564-1576.

Jabko, N. (2001) Expertise et politique à l'âge de l'euro : la Banque centrale européenne sur le terrain de la démocratie. Revue Française de Science Politique 51(6): 903-931.

Leighninger, M. (2006) The Next Form of Democracy: How Expert Rule is Giving Way to Shared Governance... and How Politics Will Never Be the Same. Nashville: Vanderbilt University Press.

López-Rabatel, L., and Sintomer, Y. (2019) Introduction. L'histoire du tirage au sort en politique : instruments, pratiques, théories. Participations Hors Série(HS): 9-34.

Luskin, R. C. (1990) Explaining Political Sophistication. Political Behavior 12(4): 331-361.

Manin, B. (1995) Principes du gouvernement représentatif. Paris: Calmann-Lévy.

Manin, B., and Blondiaux, L. (2002) L'idée de démocratie délibérative dans la science politique contemporaine : introduction, généalogie et éléments critiques. Politix (57): 37-55. 
Mayer, N. (2002) Les dimensions de la confiance. In La démocratie à l'épreuve. Paris: Presses de Sciences Po (P.F.N.S.P.).

Muxel, A. (2002) La participation politique des jeunes : soubresauts, fractures et ajustements. Revue française de science politique 52(5): 521-544.

Muxel, A. (2018) Politiquement jeune. Paris: L’Aube.

Norris, P. (2011) Democratic Deficit: Critical Citizens Revisited. Cambridge: Cambridge University Press.

Nye, J. S., Zelikow, P., and King, D. C. (1997) Why People Don't Trust Government. Harvard: Harvard University Press.

Pélabay, J., and Sénac, R. (2019) French Critical Citizens: Between Philosophical Enthusiasm and Political Uncertainty. French Politics 17(4).

Rancière, J. (1995) La mésentente : politique et philosophie. Paris: Galilée.

Rancière, J. (2005) La haine de la démocratie. Paris: La Fabrique.

Restier-Melleray, C. (1990) Experts et expertise scientifique: le cas de la France. Revue française de science politique 40(4): 546-585.

Sintomer, Y. (2011) Petite histoire de l'expérimentation démocratique: tirage au sort et politique d'Athènes à nos jours. Paris: La Découverte.

Talpin, J. (2019) Le tirage au sort démocratise-t-il la démocratie ? Ou comment la démocratie délibérative a dépolitisé une proposition radicale. Participations Hors Série: 453-473.

Tiberj, V. (2004) Compétence et repérage politiques en France et aux États-Unis: une contribution au modèle de «l'électeur raisonnant». Revue française de science politique 54(2): $261-287$. 


\section{Tables}

Table 1: Opinion on random selection of at least some decision makers according to the opinion on skills-testing of elected representatives before they take office (\%)

\begin{tabular}{|c|c|c|c|c|c|}
\hline & & At least some de & $\begin{array}{l}\text { sion-makers shoulc } \\
\text { among ordinary c }\end{array}$ & $\begin{array}{l}\text { e randomly sele } \\
\text { zens. }\end{array}$ & from \\
\hline We should test & & Disagree (0 to 3 ) & $\begin{array}{c}\text { Neither agree nor } \\
\text { disagree (4 to } 6 \text { ) }\end{array}$ & Agree (7 to 10$)$ & $\mathrm{N}$ \\
\hline $\begin{array}{l}\text { and evaluate } \\
\text { the skills of }\end{array}$ & $\begin{array}{c}\text { Disagree (0 to } \\
3)\end{array}$ & 64 & 20 & 16 & 878 \\
\hline $\begin{array}{c}\text { elected } \\
\text { representatives } \\
\text { before they }\end{array}$ & $\begin{array}{c}\text { Neither agree } \\
\text { nor disagree ( } 4 \\
\text { to } 6)\end{array}$ & 25 & 52 & 22 & 5,057 \\
\hline take office. & Agree (7 to 10$)$ & 16 & 33 & 51 & 12,078 \\
\hline & TOTAL & 21 & 38 & 42 & 18,013 \\
\hline
\end{tabular}

Table 2: Opinion on skills-testing of elected representatives before they take office, according to the opinion on random selection of at least some decision makers (\%)

\begin{tabular}{|c|c|cccc|}
\hline \multicolumn{5}{|c|}{ We should test and evaluate the skills of elected representatives } \\
before they take office.
\end{tabular}

Table 3: Opinion on random selection of at least some decision makers, according to level of education (\%)

\begin{tabular}{|c|c|c|c|c|}
\hline Level of education & Disagree (0 to 3) & $\begin{array}{c}\text { Neither agree nor } \\
\text { disagree (4 to 6) }\end{array}$ & Agree (7 to 10) & N \\
\hline No qualification, CEP & 16 & 38 & 45 & 899 \\
BEPC, CAP, BEP & 16 & 37 & 47 & 4,571 \\
BAC & 19 & 38 & 43 & 3,899 \\
University degree & 24 & 38 & 38 & 8,644 \\
\hline TOTAL & 21 & 38 & 42 & 18,013 \\
\hline \multicolumn{4}{c}{$\chi^{2}=191.1403(\mathrm{P}<0.05)$} \\
\end{tabular}


Table 4: Opinion on skills-testing of elected people, according to level of education (\%)

\begin{tabular}{|l|c|c|c|c|}
\hline \multicolumn{1}{|c|}{ Level of education } & Disagree (0 to 3) & $\begin{array}{c}\text { Neither agree nor } \\
\text { disagree (4 to 6) }\end{array}$ & Agree (7 to 10) & N \\
\hline No qualification, CEP & 4 & 25 & 71 & 899 \\
BEPC, CAP, BEP & 3 & 25 & 72 & 4,571 \\
BAC & 5 & 27 & 68 & 3,899 \\
University degree & 6 & 31 & 63 & 8,644 \\
\hline \multicolumn{1}{c|}{ TOTAL } & 5 & 28 & 67 & 18,013 \\
\hline \multicolumn{4}{c}{$\chi^{2}=163.3664(\mathrm{P}<0.05)$} \\
\end{tabular}

Table 5: Opinion on random selection of at least some decision makers, according to citizen profile (\%)

\begin{tabular}{|c|c|c|c|c|}
\hline Citizen profile & $\begin{array}{c}\text { Disagree } \\
(0 \text { to } 3)\end{array}$ & $\begin{array}{c}\text { Neither agree } \\
\text { nor disagree } \\
(4 \text { to } 6)\end{array}$ & $\begin{array}{c}\text { Agree } \\
(7 \text { to } 10)\end{array}$ & $\mathrm{N}$ \\
\hline Non-critical & 38 & 37 & 25 & 1,653 \\
\hline Demo-reformers & 23 & 41 & 36 & 8,709 \\
\hline Demo-transformers & 14 & 34 & 52 & 6,241 \\
\hline Demo-exiters & 15 & 34 & 51 & 1,410 \\
\hline TOTAL & 21 & 38 & 42 & 18,013 \\
\hline
\end{tabular}

Table 6: Opinion on skills-testing for elected representatives before they take office, according to citizen profile (\%)

\begin{tabular}{|l|c|c|c|c|}
\hline \multicolumn{1}{|c|}{ Citizen profile } & $\begin{array}{c}\text { Disagree } \\
\text { (0 to 3) }\end{array}$ & $\begin{array}{c}\text { Neither agree } \\
\text { nor disagree } \\
\text { (4 to 6) }\end{array}$ & $\begin{array}{c}\text { Agree } \\
\text { (7 to 10) }\end{array}$ & $\mathrm{N}$ \\
\hline Non-critical & 9 & 39 & 52 & 1,653 \\
Demo-reformers & 5 & 31 & 64 & 8,709 \\
Demo-transformers & 4 & 22 & 74 & 6,241 \\
Demo-exiters & 5 & 23 & 73 & 1,410 \\
\hline \multicolumn{1}{|c|}{ TOTAL } & 5 & 28 & 67 & 18,013 \\
\hline
\end{tabular}

$x^{2}=419.8831(\mathrm{P}<0.05)$

Cramér's V $=0.1072$ 


\section{Appendix}

Impact of political and socio-demographic variables on approval of random selection and skillstesting

Approval of random selection Approval of skills-testing

\begin{tabular}{|c|c|c|c|c|}
\hline & Coef. & Std. Err. & Coef. & Std. Err. \\
\hline \multicolumn{5}{|l|}{$\begin{array}{l}\text { Left-Right scale (ref: } \\
\text { l/far-Left })\end{array}$} \\
\hline 2 & $-0.48 * * *$ & 0.01 & $-0.01 *$ & 0.01 \\
\hline 3 & $-0.33 * * *$ & 0.01 & $0.02 * *$ & 0.01 \\
\hline 4 & $-0.07 * * *$ & 0.01 & 0.01 & 0.01 \\
\hline 5 (far-Right) & $-0.04 * * *$ & 0.01 & $0.06 * * *$ & 0.01 \\
\hline \multicolumn{5}{|l|}{$\begin{array}{l}\text { Citizen profile (ref: } \\
\text { non-critical citizens) }\end{array}$} \\
\hline Demo-reformers & $0.09 * * *$ & 0.01 & $0.06 * * *$ & 0.01 \\
\hline Demo-transformers & $0.19 * * *$ & 0.01 & $0.11 * * *$ & 0.01 \\
\hline Demo-exiters & $0.18 * * *$ & 0.01 & $0.12 * * *$ & 0.01 \\
\hline Interest for politics & 0.01 & 0.01 & $-0.02 * * *$ & 0.01 \\
\hline \multicolumn{5}{|l|}{$\begin{array}{l}\text { Income (ref: less than } \\
€ 1250)\end{array}$} \\
\hline 1250 to $€ 1999$ & -0.01 & 0.01 & -0.01 & 0.01 \\
\hline 2000 to $€ 2499$ & -0.01 & 0.01 & -0.01 & 0.01 \\
\hline 2500 to $€ 3499$ & $-0.01 *$ & 0.01 & -0.01 & 0.01 \\
\hline 3500 to $€ 5999$ & $-0.04 * * *$ & 0.01 & $-0.02 * *$ & 0.01 \\
\hline$€ 6000$ and more & $-0.06 * * *$ & 0.01 & $-0.02 *$ & 0.01 \\
\hline Education & $-0.08 * * *$ & 0.01 & $-0.04 * * *$ & 0.01 \\
\hline Age & $-0.09 * * *$ & 0.01 & $0.08 * * *$ & 0.01 \\
\hline Female & $0.02 * * *$ & 0.00 & $0.02 * * *$ & 0.00 \\
\hline Religiosity & $-0.02 * *$ & 0.01 & $-0.03 * * *$ & 0.01 \\
\hline Constant & $0.57 * * *$ & 0.02 & $0.64 * * *$ & 0.01 \\
\hline Observations & \multirow{2}{*}{\multicolumn{2}{|c|}{$\begin{array}{c}16,752 \\
007\end{array}$}} & \multirow{2}{*}{\multicolumn{2}{|c|}{$\begin{array}{c}16,752 \\
0.06\end{array}$}} \\
\hline $\mathrm{R}^{2}$ & & & & \\
\hline
\end{tabular}

